\title{
Waiting for the middle class society?
}

\section{Nikula, Jouko}

Routledge, Taylor \& Francis

2020-05-05

Nikula , J \& Chernish , M 2020 , Waiting for the middle class society? in J Nikula \& M Chernish (eds), Social Distinctions in Contemporary Russia : Waiting for the Middle-Class

Society? . Studies in Modern Russia , Routledge, Taylor \& Francis , London , pp. 202-213 . https://doi.org/10.4324/9

http://hdl.handle.net/10138/336278

https://doi.org/10.4324/9781003029298

unspecified

acceptedVersion

Downloaded from Helda, University of Helsinki institutional repository.

This is an electronic reprint of the original article.

This reprint may differ from the original in pagination and typographic detail.

Please cite the original version. 


\title{
10. Waiting for the Middle class society?
}

\author{
Jouko Nikula
}

https://orcid.org/0000-0003-0525-6091

Mikhail Chernysh

https://orcid.org/ 0000-0002-8169-0933

\begin{abstract}
The article discusses the importance and role of the middle classes in Russia by noting its peculiar feature as a "state-based class". A large part of Russian middle class is still working for the state and much of its growth has taken place in the public sector while the role of traditional bases for the middle class - the entrepreneurs - has remained peripheral. There are clear differences between the middle classes and the working class in many features of the work situation, incomes and housing, but the major anomaly is the uniformity of attitudes and social views of social classes. The shared concern about growing inequalities and emphasis on the primary role of the state in provision of welfare indicates the key elements of the social contract that most Russians revere. The regimes' efforts to tighten social and political control and raise nationalist fervour have not guaranteed popular support. It is clear that Russia is bound by the course that it has chosen to move towards late modernity with all its concomitant features and attempts to impose on society stricter controls meet with stiff resistance from various sectors of society that jeopardizes its political stability.
\end{abstract}

Keywords social contract, middle class, trust

\section{The Russian middle class as social actor}

The creation of the middle class in Russia has been one of the key political projects of Putin's administration during the early 2000s. The growing revenues from oil and gas have made it possible to raise wages and increase consumption, even if they are of foreign origin. In addition, programmes and national projects have had the same goals: increase incomes, reduce poverty, and pave the way to the fulfilment of the middle-class dream. The dream consists of privacy-oriented citizens who are happy with increasing opportunities for consumption and do not bother themselves with questions of democracy or politics in general. As Remington (2010: 19) notes, 'Putin and Medvedev regard spreading the virtues associated with the middle class - a welldeveloped work ethic, the habit of saving and investing for the future, modesty in consumption, an 
orientation toward stability and security - as normatively desirable and as important policy objectives'.

Throughout the early 2000s, both Putin and Medvedev and most political advisers of the government spoke about the importance of the middle class for Russia's future and about the need to ensure its stable growth. Most of the new policy programmes adopted by the government were geared to these aims - housing, wages, and lessening of bureaucracy, for example, in private business. The years of improving well-being and accumulating wealth made the Russian middle class loyal to the government. Moreover, not only the middle class, but also the working class, experienced a clear rise in their levels of living in the first part of the 2000s.

The promise of stability and improving living standards guaranteed the continuous high support of Putin. The so-called 'market social contract' consisted of maintaining high employment levels with the means of flexibility in wages and working hours and preventing social unrest with strict labour laws. Kolesnikov (2017) notes that, 'The first version of the social contract - that citizens stay out of politics in return for a share of oil revenues - worked flawlessly’.

The erosion of the social contract started after 2008, when the effects of economic recession, ignited by the Georgian war and the consequent rapid decline in oil prices, started to be felt. The recession, even if short, meant the end of the years of rapid growth and increasing fears of unemployment and a fall in living standards. Already in late 2008 Vladislav Surkov was demanding that the middle classes should be defended from poverty by protecting them from layoffs and by supporting consumption. Surkov noted that, 'The main task of the state during the slump must become the preservation of the middle class, the defense of the middle class from the waves of poverty and confusion that are coming from the West'. (Faulconbridge 2008, quoted from Wikimedia). In this, Surkov echoed Putin who in 2008 made 'expanding the middle class a national priority'.

The public mood started to sour in late 2008 and according to the Levada Center (2019), the share of those who thought that their situation was going to be worse increased from $29 \%$ in 2008 to $56 \%$ in 2011 and the share of those who argued that the country was on the wrong track in its development reached $40 \%$ in late 2008. The disillusionment of Russia's mainly metropolitan middle classes reached its apex in 2011 in the aftermath of Duma elections and continued during the 2012 presidential elections, causing a series of demonstrations in Moscow and other big cities. 
According to Zygar (2016), the Bolotnaya demonstrations turned Putin against the middle class, because the creative class had betrayed Putin. The middle class had turned out to be ungrateful for all the ingredients for a good life his administration had given them: stability, well-being, and the possibility to take out loans, travel abroad, and consume. As a consequence, the middle class was no longer ideologically the government's favourite. Even if the government continued to pursue “'middle-class friendly' policies, for example with the so-called 'May-degrees,' Putin's 'ideological gaze' turned more to appealing to the 'ordinary people' outside Moscow. The emphasis on ordinary, hard-working Russians was still more symbolic, since the practical policies did not benefit them, but on the contrary burdened them later with the 'pension reform' and new taxation, other things notwithstanding.

The change of ideological focus was accompanied by a stronger emphasis on patriotism, Orthodox faith, and traditional Russian values. Gessen (2018) argues that behind the 'conservative turn' in Russia are the ideas of Aleksander Dugin (2014), who maintains that Russian culture is inherently conservative and based on the Orthodox religion. Dugin is not any kind of key ideological thinker for the Russian Government, but more a kind of tool for the government in its efforts to create an image of Russia as a special kind of culture and the centre of the Eurasian world.

In the midst of the declining popularity of President Putin and decelerating economic growth, the second version of Putin's social contract evolved in the context of the annexation of Crimea in March 2014. The second version set out that citizens should stay out of politics in return for Russia's renewed great-power status. This effort continued in Syria, where Russia's growing presence was crucial for the successful result of the war for the al-Assad regime. This was also an effort to gather all Russians around the common cause, to defend the interests of Russia against the hostile Western culture, values (liberalism, gay rights, etc.) and political interests (NATO expansion, cornering Russia) and it played well, as the ratings of the president and the Russian Government rose rapidly back to pre-crisis levels. ${ }^{i}$ During 2016 - 2018, the glamour of Crimean events and striving for a great-power position have evaporated in the minds of many Russians as the economy lingers due to sanctions and rising consumer prices for utilities have remained as matter of constant fear throughout the 2000s until 2019. The patriotic fervour of 2014 has been replaced with concerns about the slowly deteriorating levels of living, as the government's foreign policy actions have become a liability. As Koleshnikov noted in 2017, 'Citizens begin to wonder 
what exactly they are getting from the state in exchange for abiding by the law and paying taxes. They are happy about Crimea's annexation but would also like to receive more services from the state.'

Schulman (2018) also acknowledges the power of Crimea annexation in creating a national consensus - at least for a while. According to her, 'There were superficial obvious signs of "rallying around the flag": the growth of power ratings, the level of trust and some agitation. People experienced national enthusiasm, pride, and then - fear, panic and expectation of nuclear war. In the autumn, the economic consequences of the whole festival fell on them and they experienced a range of other emotions.'

This range of other emotions included disappointment about the lack of any real signs of improvement in well-being and frustration about the continuation of inequalities and corruption. In subsequent surveys, questions about social justice and the fight against inequalities have gained the top ratings, while stability and nationalism have been losing ground. All this points to a dilemma between the tight fiscal conservatism, which Russian governments have pursued for years and demands that the Russian population has expressed for a welfare model which is accessible and equal for all social groups. The fear of external vulnerability erodes the financial basis of social services and education, compelling the government to withdraw from the provision of necessary services. This provides a basis for an increasingly private system of welfare services, where freedom of choice is possible only for those who can afford it. The working class and even the majority of the wage-working middle class are not among them.

\section{Waiting for the middle class - Social change in Russia since the late 1990s}

Our analysis has proved again that it is too early to announce the death of social classes, but the transition of Russia changed class relations fundamentally. Twenty years ago, the working class was clearly the main social class: over $60 \%$ of the economically active population belonged to the working class. The contemporary working class is only $2 / 3$ of that and its ideological position is completely different from how it was 30 years ago. The working class was ideologically the driving force of socialist society, but after the collapse of the Soviet Union, it suddenly became incorrect to talk about the working class any more. The structure and social composition of the working class is changing. The share and absolute numbers of the service sector is growing and the 
industrial working class is declining. This means that the share of women in the working class is increasing. The working class is weak; it has practically no organizational power resources, becauseonly about one-third of all workers are unionized. Not only are the trade unions weak, but there are major differences in their bargaining power across the country. There are labour protests, but many of them are local, sporadic events. Labour protests in Russia are almost all either wildcat actions or actions by independent unions. (see Crowley and Olimpieva 2017.)

The middle class was to become the new avant garde of society. It was supposed to be a social group that was positively disposed towards the authorities, more supportive, and less critical of its policies. The middle class in Russia is a heterogeneous entity, containing many sub-groups with vastly differing situations in terms of income and work. One large group is white-collar professionals in the public sector, such as teachers, librarians, and nurses. The majority of them are highly educated but low-paid members of the middle class, who are dependent on the state and therefore support the strong role of state in society. Entrepreneurs represent the new middle class, and for them the state represents an obstacle to the development of a healthy economy and, instead of guaranteeing and safeguarding enterprises, punishes them with unclear and erratic policies.

However, despite the public speech by the Russian political elite, which argues that small and medium-sized enterprises are one of the main platforms of the middle class, entrepreneurs do not occupy any important political or ideological position.

Many efforts towards indirect support for entrepreneurship have been initiated in Russia since 2000. These have included such measures as tax reform, cutting red tape, and lowering entry costs. However, despite these federal laws, their impact has remained quite limited. The main reason for failures in creating an effective system of measures for entrepreneurship is, according to Chepurenko (2011) the predominantly ad-hoc type of policy.

\section{Is there a middle class in Russia?}

Thomas Remington (2010: 33) noted that the middle class is an elusive target. Its size and shape shift depending on how it is conceptualized and measured. Therefore, there is substantial doubt as to whether there is any single social group that merits being classified as a middle class at all. Remington also noted the futility of trying to measure the size of the middle class with income data, occupation or self-identification, because these indicators give exactly the size of the middle 
class that one wishes - ranging from $20 \%$ up to $60-70 \%$. Despite the general improvement in living standards in Russia, the short period of economic growth during 2001-2008 did not act as a basis for the growth of the middle class. As Remington (2016) notes, 'In neither country [USA/Russia] the middle class expanded at anything like the same rate as the growth in average incomes'. The most significant tendency in Russia has been the rapid growth of income inequality - 'the concentration of income increases (both in pre- and post-tax and transfer incomes) in the highest income strata' (Remington 2016).

It is also well-known that in Russia the level of education and level of income does not necessarily match; well-educated professionals, especially in the 'budget sector' (education, research and healthcare) are low-paid and vice versa, highly paid groups (such as entrepreneurs) are often less well-educated. In Russia, high education or occupation do not represent a reliable basis for social esteem, because the subjective identification does not correspond practically at all with people's real material or social situation. (see Bavin 2006.)

The above-mentioned problems of defining the middle class are also related to the inability to see the qualitative difference between statuses in socialist and post-socialist society. The social status of a medical doctor in Soviet society is completely different from the status of a doctor in postSoviet society. A related failure is the inability to take into account the fact that a large part of the middle class was, and still is, employed by the state. This means that the old middle class, inherited from Soviet society, such as teachers, nurses, librarians, social workers, and others, are quite different kinds of members of the middle class than those members of the new middle class who are employed by the private sector in finance, IT, or the energy sector. Not only are their material statuses different, but also many features of their work and interests.

In $2015,{ }^{\mathrm{ii}}$ almost $45 \%$ of the middle class was working in the public sector, down from over $75 \%$ in 1991 and $65 \%$ still in 1998. The division of the middle classes into the private and public sectors has significant implications, for example, in their work situation. Public sector employees enjoy more secure employment and better benefits than private sector employees. It suffices to note that 65-69\% of employees in the public sector get sick pay from their employer, while among the private sector the share is $46 \%$. Nearly $60 \%$ of employees in the public sector had a trade union organization in their workplace, while in the private sector this was the case only for $13-15 \%$ of middle-class employees. 
Wages in Russia have grown a great deal since the economic crisis at the end of the 1990s. Compared with 1998, the differences in median incomes between the middle class and the working class have declined, but internal differences within the middle class have grown. The wage gap between the genders has remained the same and is largest in the extractive and trade industries as well as in science and research. Jobs in teaching, social welfare, and health services are still at the low-paid end of the scale. As Chernysh notes in this volume, the wage winners of recent years are workers in the extractive industry, finance, and defence, as well as in public administration.

One of the main elements in increasing well-being has been housing, where the state's withdrawal from most areas related to housing - maintenance, provision of public housing - and the emergence of the mortgage markets turned Russia into a nation of 'super-home ownership, as Khmelnitskaya and Burdyak demonstrate. This has undoubtedly had many impacts among Russians. Ideologically, home ownership represents a form of 'people's capitalism', where each member of society has the possibility to be a property owner. Home ownership nurtures feelings of a more stable and predictable life, which is clearly part of middle-class values. The governments' ultraliberal policies and reforms have also had many unintended consequences; in the conditions of a stagnating economy and increasing prices of utilities, home ownership has turned into a burden for many. Housing also acts as a basis for social activism, as the news about Moscow's protests in $2017^{\mathrm{iii}}$ against the demolition of khrushchyovkas demonstrated.

As Chernysh argues, the class differences in Russia are widening, as the upper classes are drifting apart from both the working and lower middle classes and rural workers are joining the lower part of the working class. The urban part of the unskilled working class, both Russians and migrant workers from former republics of the Soviet Union, such as Uzbekistan and Tadzhikistan, represent the core of the Russian version of the precariat. They are the ones who are most susceptible to employment precarity during periods of crisis and economic downturn. Therefore, we can agree with Yulia Epikhina that 'we should view precarity not as the cause of class differentiation but rather as the result of the already established class stratification, where finding oneself on the lowest hierarchy levels under unfavourable economic circumstances makes precarity far more likely'. In this, she echoes Melin $(2018,10)$, who notes, 'Rather than just about inequality, precariousness - and the precariat - is about many-dimensionally understood 
vulnerability. When we talk about precarious social positions, we often talk about vulnerable people.'

However, contrary to views by Standing (2011), the precariat in Russia - or anywhere else - is not a separate class and certainly not a dangerous class. The precariat is very diverse group, including divergent and disconnected groups from the lower middle and working classes, and therefore they have very little resources to articulate or defend their interests.

The golden years of Russia between 2001 and 2008 almost halved the poverty rate and improved the absolute well-being of large segments of the Russian population. Currently the share of the poor $^{\text {iv }}$ is still quite low (13.4\%) in Russia and concerns predominantly the peripheral areas of rural Russia. Another sore point in Russian social geography is the mono-towns, where the policies of diversification and reform have not produced long-lasting or sustainable results. Therefore, the focal points of poverty are peripheral rural villages and small cities, where as much as a quarter of the working class and 16-18\% of the middle class are poor. Middle-class affluence concerns mainly only residents of Moscow and a few other bigger cities.

One of the indicators of the constantly growing disparities between the urban and rural is the higher prevalence of both societal and attitudinal anomy in small rural communities. The decades of stability and the oil miracle have not stretched to all groups in Russia, and the low levels of confidence and high levels of social or attitudinal anomy indicate maladaptation to social change. As Mannila and Kainu note, 'Social anomy is a feature of social exclusion, an element of a vicious circle'. The golden years have also proved to be a disappointment for a small portion of the middle class, and their frustrated expectations are indicated by attitudinal anomy and low confidence. Part of the highly educated Soviet middle class lost their status, incomes, and employment in the collapse of socialism as early as during the 1990s and have not been able to adapt to the market economy.

The Russian middle class is politically and in terms of social activity rather passive: $70 \%$ of the members of the middle class do not take part in the activities of any organization, i.e. political parties, trade unions, or voluntary organizations. However, the passivity concerns mainly institutionalized and organized forms of participation, and the middle class is more active in less organized and regular events, such as the celebration of Victory Day and political rallies. 
At the attitudinal level, the middle class do not differ from other classes: they support the rule of law and only a quarter of them prefer a strong leader to democratic practices. The middle classes also share concerns about the threat posed by the growing income differences in Russia and agree that the government should reduce them. They also strongly favour the state over the private sector in the provision of healthcare and most forms of social services, as Sippola and Järvinen demonstrate. The other side of the coin is the quality of services, which a majority of members of both the middle and working class consider poor. As Sippola and Järvinen conclude, 'the Russian Government should not neglect the fact that a majority of Russian respondents perceived the performance of the welfare state as bad. [...] in compliance with previous literature (e.g. UNRISD 2015), the performance of the Russian welfare state is perceived as bad, although people would prefer 'social security over efficiency'.

The strong view on the priority of social security over efficiency comes out clearly from many studies of the Russian welfare state. People are worried about health services and education - two services that have been most ardently transferred from being the responsibility of the federal state to the responsibility of regional governments and various private actors, enterprises, or nongovernmental organizations, or combinations of these. Schulman (2018) notes that 'That is still the state "should"... But the paternalistic consciousness is changing, unfolding in a different way. People still believe that the state should do a lot of things that it does not do, but this obligation is changing. [The state] should provide fair wages, health care, and material support to citizens directly. But educated people continue to consider their own responsibility.'_Dmitriev,., Nikol'skaja,, Belanovskij, and Cherepanova, $(2018,1)$ note, that the past counter-elite populism has been replaced by a demand for freedom, honesty, respect and peace, now prevailing over basic material needs.' There is also a request for equality of all before the law. The respondents in the study did not trust authorities, whom they see as dishonest and possessing double standards, but at the same time they feel the distrust of the authorities to them. The most important feature that Dmitriev and others found, was the increasing sense of personal responsibility for the state of affairs in the local community and in the country as a whole and this finding gives them reason to believe that there are 'signs of development of renewed modernization of mass consciousness, for the first time since 2012' (ibid, 6). 


\section{Diverging social views}

The common story for most societies which have experienced rapid social change is that injustice, crime, and corruption reign. In those circumstances, such features as hard work, honesty, and law abidance are not the means to wealth and power. This was the case in Russia during the early 1990s, when properties changed hands and murder rates soared together with mortality and poverty. Since the turn of the century, matters have improved to some extent: the growing wellbeing has meant less poverty and less crime, at least in urban areas. However, corruption and blat relations seem to be a perennial problem in Russia, as Navalny and other members of the opponents of the current government, together with academics and even members of the State Duma, argue. The government does not deny that the level of corruption is high, but their efforts have been quite unhelpful, because until now they have mainly claimed that they are doing what they can to restrain it, while in fact they are part of the corruption, as the case of the Minister of the Economy Ulukaev shows.

The Levada Center polls Russians regularly and asks whether they think that the country is heading in the right direction. Still in the late 1990s and early 2000s, three out of four respondents said that the country was on the wrong track, and only after 2007 did a majority of respondents say that the country was moving towards the right direction. The Life in Transition Report (EBRD 2010) also confirmed that at least in terms of the economy, the situation had definitely improved.

In the wider perspective, the views about the preconditions for success in society have followed quite closely the turns and upheavals in Russia. In 1988 the important factors for success in society were mostly 'personal or individual virtues', things that are valued almost universally: good education, hard work, persistence in attaining goals, intellect, and to a lesser extent luck. In those days, having relations abroad or rich parents or living in the capital did not matter that much for the majority of people. Ten years later, the order of important factors was quite different: the most important were useful connections (blat relations), family members in managerial positions, and rich parents. Hard work and persistence, not to mention honesty or law abidance were not important success factors for most Russians.

Nowadays, the modern Russian mind-set embraces the value of individual freedom and regards the values of personal success and self-fulfilment as the most important in society. This group of people, as Mastikova argues, 'shows initiative, is not inclined to delegate their own success to 
others, and does not expect any help from government institutions or officials. These respondents feel that their success will be their own doing, believing that they will need to work hard and remain resilient.' Something about the stabilization and 'normalization' of the society demonstrates the fact that among the Russians are those who think 'that, if they do not break the law, do everything by the book, and treat their personal and workplace partners honestly, they will earn the respect of their peers, proving themselves worthy of career growth and, therefore, success in life'.

The 'traditionalist mind-set' (Mastikova), which supports the major role of the state to 'ensure the safety of both the community and each individual member thereof,' is another and necessary side of the modern mind-set in the context of the modern Russia, where welfare, education, and many other necessities of life are transforming from being universal into being means-tested and restricted.

Mastikova's analysis also proves the fact, that the thesis about the harmful legacy of socialism for people's minds - the 'kolkhoz' mentality or learned helplessness - does not hold true, at least not entirely. The young and educated, with good incomes and positions in the labour market - i.e., members of the middle class - are ready to change their lives and look at 'the future Russia as a country with well-developed social services and free healthcare and education, like Finland or Germany'. The older generation, less well-educated and living in small towns and rural areas, feel at a loss when facing the future and are not willing to change anything. For them the best option is for Russia to be a socialist country like the USSR.

A different kind of view about the state of mind of Russians is given by Ekaterina Schulman (2019), who claims that the argument about 'Collectivism [which] raised a lonely, distrustful man with broken social skills,' is not completely true. A more factual interpretation, according to Schulman, is that the Russians have been acquiring the necessary social skills over the past 25 years, not because of any state efforts or government programmes, but because of the ties between people. This all means that people are learning to work together. In terms of political activity, it means that since trust in the establishment has decreased and there is a lack of serious political opposition to articulate popular concerns about inequality and deteriorating social services, activity is taking place more within various civic groups. These groups, which are gradually building 
relations of trust with local populations, are highlighting separate issues, such as pensions, education, or waste disposal.

This would indicate that even if there are no credible opposition parties or strong trade unions, and even if the protests are predominantly isolated events on single issues, the Russians are not passive. There are also signs of somewhat vague populist forms of protest, combining leftist slogans about confrontation with corrupt oligarchs and nationalist demands to protect the Russians from the threats of NATO and terrorism, represented by immigrants. The political field in Russia is still very amorphous, because there are no credible alternatives in either the left or liberal wings of the political spectrum.

As Kivinen notes, the fact that that there are no empirically observable differences between the classes in terms of in class-consciousness, organization and class agency is quite a surprising anomaly in the Russian context. In many attitudinal questions on welfare or politics, the views are quite similar across classes. As a first explanation for this anomaly, Kivinen finds rapidly increasing levels of well-being for all social groups, reinforced by the large-scale privatization of housing, making most Russians property owners. Another cause of the apolitical homogeneity of the Russian population, the increasing atomization of reality, refers to the fact that people feel unable to influence almost anything: rising living costs, the fate of the peripheries, and especially in rural areas, corruption. At the same time, people feel that the government has betrayed the promise of the social contract by making increasingly unpopular decisions. However, recently this sort of social anomy has shown signs of waning, with large protests taking place not only in Moscow, but also increasingly in other regions of Russia.

These protests have concerned local elections, construction projects, waste management, and violence by public officials against citizens. Polls by the Levada Center and Carnegie are also indicating that there is a growing demand for social change in Russia, because living standards have stagnated or declined almost constantly since 2008, and governments' efforts to maintain their legitimacy through various national projects and military operations have either failed or their impacts have faded. Our data does not give the opportunity to test very closely the extent to which the social atmosphere is changing in Russia, but it seems safe to agree with Kolesnikov, who argues that, "There is an obvious awakening of civil society, the "revolution of dignity" turns into a permanent process'. However, at the same time there is no very strong reason to expect any sudden 
social upheaval led by any of the social classes in Russia. The middle class is still too heterogeneous and divided in its interests to act as a unified social force, while the working class is still marginalized both ideologically and politically and a kind of taboo in Russian society. Both the middle and working classes lack organizational capabilities in terms of trade unions, parties or other organizations to articulate their interests or organize actions. Therefore, we still have to wait for Russian middle-class society to become the social force it was expected to become almost nearly three decades ago.

\section{Necessary choices facing the uncertain future}

The 'oil and gas' empire proclaimed by President Putin in the mid-2000s no longer looks like a promising project with a glut of oil on the international market and few easy resources to be tapped in those parts of the country with easy access. The nationalist cause has been widely discredited by the Ukrainian national revolution which created more problems than it solved. There is a growing realization in society that the nationalist path is fraught with internal conflicts. Then what are the options available to Russian society? The recent debates have highlighted several key dilemmas that Russian society faces. The first poses a choice between economic growth and economic decline. The resumption of growth is only possible if economic reforms start addressing important issues such as the existing system of taxation, declining infrastructure, creation of viable options for investment, and reining in bureaucracy including the omnipotent law enforcement agencies. Many of the issues that are deemed economic are in fact rooted in society and Russian politics. The social justice policy cannot be implemented without reforms of taxation and viable trade unions capable of standing up to the government and employers.

Key institutions of reproduction - healthcare and education - should get more government money, not less. Large-scale projects to renovate the existing infrastructure need a policy of governmentled investment and in the same breath an effective policy to curb corruption in high places. Reining in bureaucracy is a policy that implies the development of civic society and responsible and effective local governments. If economic growth resumes, Russia will be in a better position to improve its relations with the West. Its economic decline creates few incentives for Western countries to engage in productive economic and political exchange. Exclusive emphasis on military superiority does little to endear the Russian Government to its Western counterparts. On the other hand, a dynamic economy can be a good starting point for maintaining mutual interest 
and political exchange. A better and fair system of distribution and effective social policy can make Russia more attractive to its immediate neighbours, a better model to be emulated by some of the former Soviet republics. The alternative to economic growth is the current policy of gradual decline and political stagnation.

Russian society is only midway between Soviet-type socialism and a new system, the contours of which have not yet been fully defined. The change that the study highlights is non-linear: it reflects the complexity of the processes unfolding in society, the economy, and the public consciousness. The differentiation process which the project made salient has led to deep rifts in society and obvious tensions. Nevertheless, it is also contributing to the formation of structures that are far more varied than anything that has ever before been observed in Russian society. In this respect, Russian society is becoming more modern, characterized by a greater variety of social positions, occupations, and lifestyles. More acute problems are plaguing it than typically arise in differentiated modern societies. Hence the response towards profound change - an attempt, although unconvincing, to rely on traditions that go back to either pre-revolutionary times or Soviet times that are often associated with stability and development. However, as the study shows, there is little possibility of embracing any of the old patterns. Russia is bound by the course that it has chosen to move along towards late modernity with all its concomitant features. Attempts to impose stricter controls on society meet with stiff resistance from various sectors of society which jeopardize the political stability. Stricter controls are defied by a greater number of Russians who use modern technologies, engage in sophisticated consumption patterns, travel abroad, or choose to look for better fortunes in other countries. The contradiction between an ever more complex society and attempts to impose on it obsolete restrictions is bound to be the greatest challenge that Russian society might face in the near future. 


\section{References}

Bavin, P. 2006. Waiting for the middle class, Social Reality, 1, available from (http://socreal.fom.ru/english/?link=ARTICLE\&aid=59).

Chepurenko, A. 2011. Entrepreneurship and SME policies in fragile environments: The example of Russia. Handbook of Research on Entrepreneurship Policies in Central and Eastern Europe.Edward Elgar, Cheltenham

Crowley, S. and Olimpieva, I. 2017. Labor Protests and Their Consequences in Putin's Russia. Problems of Post-Communism. 1-15. 10.1080/10758216.2017.1364135.

Dmitriev, M. E., Nikol'skaja, A. V., Belanovskij, S. A., Cherepanova, E. V. 2018. Osennij perelom v soznanii Rossijan: mimoletnyj vsplesk ili novaja tendencija? Fond liberal'naja missija. Dekabr'. (Autumn break in the minds of Russians: A fleeting surge or a new trend?)

Dugin, A. 2014. Eurasian Mission: An Introduction to Neo-Eurasianism, ed. Morgan IV, J.B., London: Arktos.

EBRD 2010. Life in Transition II: After the Crisis, London: EBRD.

Faulconbridge G. (28 November 2008). "Kremlin says to defend Russian middle class in crisis". Forbes

Gessen, M. 2017. The Future is History: How Totalitarianism Reclaimed Russia, London: Granta Books.

Kolesnikov, A. 2017. New protests question Russia's social contract, Carnegie Europe, 16 June, available from https://carnegieeurope.eu/strategiceurope/71283.

Kolesnikov, A. Volkov,D.. 2019. My zhdem peremen - 2. Pochemu i kak formiruetsya spros na radikal'nye izmeneniya. Moskovskij Centr Karnegi. 06 Noyabrya

Levada Center 2019. Approval ratings, available from

https://www.levada.ru/en/2019/11/11/approval-ratings-9/

Melin, H. 2018. Working life and the myth of precariat in Russia. A paper presented at BASEES/Uppsala Conference 2018: Regimes and Societies in Conflict: Eastern Europe and Russia since 1956. 13.-14.9.2018, Uppsala, Sweden

Remington, T.F. 2011. The Russian middle class as policy objective, Post-Soviet Affairs, 27(2): 97-120, DOI: 10.2747/1060-586X.27.2.97

Shulman, E. 2019. Kakoy dolzhna byt vlast v Rossii I chego zhdet narod, available from: https://www.znak.com/2019-01-

09/kakoy_dolzhna_byt_vlast_v_rossii_i_chego_zhdet_narod_lekciya_ekateriny_shulman

Standing G. 2011. The Precariat. The New Dangerous Class, London: Bloomsbury. 
Vinogradova, E., Kozina, I., and Cook, L. 2015. Labor relations in Russia: Moving to a 'market social contract', Problems of Post-Communism, 62: 193-203.

Zygar, M. 2016. All the Kremlin's Men: Inside the Court of Vladimir Putin, New York: Hachette.

\footnotetext{
i Putin's approval rate rose from $63 \%$ to $85 \%$ and the government's rating rose from $43 \%$ to $60 \%$ within a year in 2013-2014.

ii Figures from SDMR-2015 data.

iii Reuters World News, 14 May 2017

iv The poverty line is officially defined by the minimal wage level of 11,500 rubles(about 150 Euros), which means that the share of the poor is $12 \%$. In surveys, the share of those who feel that they can hardly make ends meet is close to $18 \%$.

${ }^{\vee}$ Ulyukaev was detained and dismissed from his ministerial position in November 2016 after allegations of taking a $\$ 2$ million bribe. At his trial he was found guilty and sentenced to eight years in a strict-regime labour colony and fined 130 million roubles.
} 